\title{
Is Teamwork Different Online Versus Face-to-Face? A Case in Engineering Education
}

\author{
Julian Goñi ${ }^{1, * \mathbb{C}}$, Catalina Cortázar ${ }^{1}$, Danilo Alvares ${ }^{2} \mathbb{(}$, Uranía Donoso ${ }^{1}$ \\ and Constanza Miranda ${ }^{1}$ (D) \\ 1 DILAB School of Engineering, Pontificia Universidad Católica de Chile, 7820436 Santiago, Chile; \\ ccortazar@ing.puc.cl (C.C.); usdonoso@uc.cl (U.D.); csmirand@uc.cl (C.M.) \\ 2 Department of Statistics, Faculty of Mathematics, Pontificia Universidad Católica de Chile, \\ 7820436 Santiago, Chile; dalvares@mat.uc.cl \\ * Correspondence: jvgoni@uc.cl
}

Received: 23 October 2020; Accepted: 7 December 2020; Published: 14 December 2020

\begin{abstract}
Teamwork has been systematically studied in engineering education as an educational method and a learning outcome. Based on the recent advances in socially-shared regulation as a framework for teamwork processes, this study explores the impact of the transition to online learning. The purpose of this study is to understand if face-to-face and online team dynamics differ concerning the prevalence of personal goals, team challenges, and individual/social strategies. The Adaptive Instrument for Regulation of Emotions (AIRE) Questionnaire was used to compare two semesters in project-based learning engineering courses that were face-to-face (2019) and then converted to an online modality (2020) due to the COVID-19 crisis. Our results show that both modalities report mostly the same prevalence of goals, challenges, and strategies. However, online students tend to manifest a significantly lower prevalence of specific challenges and strategies, suggesting that online teamwork may have involved less group deliberation. These results provide evidence for the "equivalency theory" between online and face-to-face learning in a context where all systemic levels transitioned to a digital modality. These findings raise the question of whether online teaching encourages the emergence of team conflict and deliberation needed for creative thinking.
\end{abstract}

Keywords: online learning; teamwork; engineering education; digital teamwork; socially-shared regulation of learning; team conflict; project-based learning

\section{Introduction}

During the last decade, an extensive debate has been ignited over the contents of engineering education. Notably, the development of professional skills during undergraduate engineering studies has gained attention and has become one of the most relevant educational priorities [1]. This emphasis may be related to the fact that the industry demands that new engineers possess communication, persuasion, leading, and teamwork skills besides having the right technical aptitudes [2,3].

Given this increasing interest and the industrial desires to pay more attention to these skills, the Accreditation Board for Engineering and Technology (ABET) determined that accredited universities ought to incorporate professional skills in their curricula, for example, critical thinking, lifelong learning, and teamwork [4,5]. In turn, ABET-accredited programs have had to analyze their curricula to foster the development not only of the traditional technical abilities that characterize engineering work but also the aforementioned professional abilities that are becoming increasingly relevant in the workplace [6].

Teamwork has been one of the main expected learning outcomes of engineering education and one of the most discussed and implemented teaching methods [7]. Team projects have been a commonly used strategy in first-year or cornerstone and capstone courses at the undergraduate 
level [8]. Moreover, the use of project-based and problem-based learning (PBL), in which teams of students tackle engineering challenges, has seen significant growth as an educational tool and research field over the last few years [7].

Despite this interest in teamwork, both as a learning outcome and as a teaching strategy, the understanding of how it is taught and learned is still underdeveloped that most universities worldwide have transitioned to online learning due to the COVID-19 crisis, understanding how students enact teamwork and how it is supported is extremely relevant in $2020[9,10]$

This article explores and compares the experience of two cohorts of undergraduate engineering students in an engineering design major from a selective Latin American university. This particular major holds a curriculum where teamwork is present in most of the courses. The teams face projects related to data visualization and the physical construction of prototypes. These particular courses had to reinvent and convert themselves to an online modality due to social revolts and COVID-19, which limited physical presence in campus and labs. The first cohort of students (2019) worked in face-to-face collaboration, while the second cohort (2020) collaborated using online tools, as the whole university was transitioning to e-learning. We base our inquiry on the socially-shared regulation of learning framework (SSRL), as described by researchers such as Hadwin and Oshige [11] and Panadero and Järvelä [12], to conceptualize teamwork under a consistent and evidence-based theory.

\section{Theoretical Framework}

\subsection{Teamwork as an Educational Method for Engineering Education}

Different types of educational methodologies involve team projects or teamwork in engineering education. Amongst them, problem and project-based learning (PBL) have been the most predominant [13]. Problem/project-based learning can be defined as "an instructional learner-centered approach which empowers learners to conduct research, integrating theory and practice to solve a defined problem or to lead to the production of a final product" [7]. In order to create a solution or research a topic, PBL usually involves students working in groups [7].

PBL has been widely adopted in engineering education for the last 50 years [14]. PBL has been implemented at course level, intercourse level, curriculum level, and external project level using different student's team compositions tackling different types of projects and under different project durations. In order for PBL to be successful, continuous PBL skills training for students is required [14]. These skills comprise different abilities, such as managing conflict, dealing with free riders, and effective communication [14]. Other factors such as group formation have a significant impact on the learning experience in PBL. Students tend to prefer teammates based on friendship and similarity in attributes such as being hardworking, flexible, and helpful [15] even though diversity and group conflict can drive innovation in engineering-design teams [16].

It is important to note that, by using teamwork as a teaching strategy (for instance, through PBL), practitioners seek to foster a series of learning outcomes such as multidisciplinary knowledge and skills, critical thinking skills, and, of course, teamwork skills [14]. In this sense, teamwork as an outcome is only one of the expected results of teamwork as a teaching strategy.

\subsection{Teamwork as a Learning Outcome for Engineering Education}

Despite the fact that there is a consensus regarding teamwork as an essential component of engineering education $[3-5,17]$ teamwork skills seem hard to define $[18,19]$. Engineering faculty tend to teach teamwork skills in less structured ways than other constructs such as effective communication [19]. Students tend to value its importance very differently at the beginning of their undergraduate studies, near the end, and entering the workplace [18]. In this sense, teamwork is consistently depicted as a central learning outcome of engineering education, even if there is still a need to create more understanding about its meaning. 
According to the literature review conducted by Chowdhury and Murzi [17], engineering education, management, and psychology research show that there are eleven attributes of successful teams. These attributes are:

(1) Shared goal/value

(2) Commitment with team success

(3) Motivation (with the task)

(4) Interpersonal skills

(5) Open/effective communication

(6) Constructive feedback

(7) Ideal team composition

(8) Leadership

(9) Accountability

(10) Interdependence

(11) Adherence to team process and performance

The list of attributes generated by Chowdhury and Murzi [17] shows a considerable complexity in terms of the different levels of analysis. Some of these attributes may be "attributed to" particular individuals (commitment with team success; motivation, interpersonal skills, open/effective communication, constructive feedback, leadership, and accountability), while others are distinctively operating at a group level (shared goal/value, ideal team composition, interdependence, and team process). Furthermore, some of these attributes can be categorized under Pintrich's model [20] as cognitive (e.g., constructive feedback) while others are motivational/affective (e.g., shared goals/values), behavioral (open/effective communication), and contextual (ideal team composition).

Paoletti et al [21] describe effective teamwork in engineering education as a set of behaviors that can be categorized under the following six dimensions:

(1) Communication

(2) Cognition

(3) Coordination

(4) Coaching

(5) Cooperation

(6) Conflict management

Some of these teamwork behaviors can be detected at individual and team levels [21]. This observation is consistent with the review of Chowdhury and Murzi [17] in the sense that some teamwork skills depend mostly on the individual (e.g., interpersonal skills), while others are attributes of the whole team (e.g., shared goals). Additionally, these behaviors also relate to different aspects of regulating learning [20]; cognitive (cognition), motivational (coaching and conflict management), and behavioral (communication, coordination, and cooperation).

In sum, teamwork as a skill seems to englobe a series of diverse cognitive, motivational, and behavioral skills. Additionally, teamwork skills can be explored from the lens of individuals and teams. To account for this complexity, there is a need to incorporate conceptual frameworks and theories into engineering teamwork research from disciplines such as educational psychology that have accumulated a significant amount of research on this topic [9]. This study bases its understanding of teamwork processes on the recent advances of the socially-shared regulation of learning (SSRL) framework, as it involves the different dimensions of learning regulation (cognitive, motivational/affective, and behavioral) while also recognizing that these processes occur both at individual and group levels. 


\subsection{Socially Shared Regulation of Learning}

Motivation and emotion regulation are considered central elements of collaborative learning [22]. As discussed in the previous section, effective teamwork requires individual motivation and shared motivation among team members [17]. In that sense, motivation needs to operate both at individual and group levels. The same is true about the behaviors involved in effective teamwork [21]. Overall, teamwork requires individuals to regulate their own behaviors, cognitions, motivations, and affections (self-regulation of learning) as well as groups to collectively do the same, that is, to perform a socially-shared regulation of their learning [23].

Socially-shared regulation of learning is a conceptual framework that, through the incorporation of sociocultural and situational concepts and perspectives, expands the self-regulation theory to study group processes and collaborative learning [12]. The SSRL framework argues that students working in teams collectively regulate their learning processes [12]. The assertion that collective learning requires that team members regulate their learning process as a collective does not imply that other forms of regulation do not occur. Under the SSRL framework, it is assumed that, in successful teamwork, three types of regulation take place simultaneously [24]. Each team member regulates his own behavior (self-regulated learning), each member helps and supports their fellow students to regulate their learning (co-regulated learning), and the groups coordinate their learning together (socially-shared regulation of learning). As Järvela and Hadwin [25] pointed out, the idea of learning regulation implies that learning is intentional, directed at goals, and conflictive in nature. In other words, students regulate to achieve a determined learning goal and to face the challenges that arise while collaborating with others. These learning challenges can be categorized under three labels [26]:

(1) Cognitive challenges: Difficulties in understanding the task or solving a problem/performing the required task. Cognitive challenges can also be identified when team members report differing skill levels and or differences in concentration.

(2) Emotional and motivational challenges: Negative emotions such as anxiety, annoyance, or frustration or problems in controlling them. Emotional challenges can also be identified as physical discomfort and lack of self-efficacy, interest, or overall energy.

(3) Social and interaction challenges: Difficulties related to working styles, communication, or contextual issues, such as lack of time or space or frustration with the technology used for the task.

In organization studies and organizational psychology, other typologies of team challenges can be found, mostly under the label of team conflict. The review conducted by Turner [27] shows that most organization scholars use a tripartite typology of team conflict comprising (A) task conflict (disagreements about the team task), (B) process conflict (disagreements about task strategies, delegation of duties, and resources), and (C) relationship conflict (disagreements about personal and social behaviors of the teammates). Ultimately, the different typologies of learning and teamwork challenges share specific attributes and emphasize various aspects of teams' social dynamics.

Learning regulation does not only occur as a result of team challenges/conflict but also as direct learning towards a goal [25]. Goal-orientation theory [28] has classically distinguished between two different types of learning goals:

(1) Mastery goals refer to an individual's purpose of developing competence, which means learning, understanding, developing skills, and mastering information. Mastery goals focus on the process of learning.

(2) Performance goals refer to the purpose of demonstrating competence, which means managing the impression that others have of their ability, attempting to create an image of high ability, and avoiding creating an impression of low ability. Performance goals focus on the outcomes of learning.

Overall, the SSRL framework depicts teamwork as an individual (self-regulation) and a group level process (socially-shared regulation). Regulation of learning is seen as reacting to the emergent 
team challenges and is directed at achieving learning goals. These elements-self and social regulation activities, team challenges, and learning goals-describe the different aspects involved in teamwork and are consistent with the reviews by Chowdhury and Murzi [17] and Paoletti and colleagues [21].

\subsection{Digital Teamwork and the Digital Transition}

The COVID-19 health crisis of 2020 involved a massive online transition of higher education institutions worldwide [10]. Based on that premise, Simonson, Schlosser, and Hanson [29-31] proposed an "equivalency theory" between online and face-to-face education. Equivalency theory posits that the more similar the learning experiences of distance learners are to those of face-to-face learners, the more similar the educational outcomes will be for all learners [30-32]. This hypothesis has received evidence to support the idea that distance learning yields relatively similar results as local education [32] or even better results [33]. Teamwork, as an educational practice, an outcome, and the experience of a socially-shared regulation of learning, may share some similarities when implemented face-to-face and online.

However, as Vygotsky [34] classically pointed out, learning is co-constructed between the cultural mediators and the learners. In that sense, it is expected that, when the teaching tools change, the learning experience and the outcomes will change as well. For instance, the research conducted by Vance, Kulturel-Konak, and Konak [35] showed that STEM students tend to have better attitudes towards teamwork when working face-to-face relative to digital teams. Online students tend to prefer individual work over teamwork, even though both face-to-face and online students report a similar satisfaction level with the results after finishing the program. The research conducted by Garratt-Reed, Roberts, and Heritage [32] showed that online students report practically equal learning outcomes compared to face-to-face students except when compared to teamwork satisfaction. To the authors, these results indicated that online students tend to be more independent and self-directed learners. This conclusion is also supported by the research conducted by Lin [36] that observed that communication and coordination difficulties are likely to occur in virtual teams due to the online tools and format. For instance, students not receiving immediate responses affected satisfaction with teamwork.

In conclusion, recent research shows that, even if the project outcomes may be similar when groups are working face-to-face and in a digital environment, the collaboration challenges and perceptions may differ significantly $[32,35,36]$. This evidence may point out that teams are regulating the challenges of teamwork in different manners. For instance, if teamwork satisfaction is lower online, it may indicate that students tend to atomize labor division more when compared to face-to-face teams [32]. In other words, they may tackle collaboration challenges with a greater prevalence of self-regulation strategies over engaging in socially shared regulation.

On the other hand, equivalency theory [29] should be analyzed in consideration to the overall systemic transition to online. From an ecological perspective [37-39], the human development and learning process is embedded in the different systemic levels in play. According to Bronfenbrenner [39], behaviors at a particular educational institution (microsystems) are also connected with the characteristics of the educational system at large (exosystem) as well as the overall cultural setting and global condition (macrosystem). In that sense, equivalence theory [29] should also be analyzed based on the discrepancies and the similarities between micro exo and macro systemic levels. For instance, the experience and the regulation strategies adopted by online teams may have changed during this health crisis due to the overall systemic change that has forced most regions of the world to adapt and utilize digital tools more often to chat with relatives, buy goods and services, and conduct other tasks of social lives that were previously performed face-to-face.

Our study explores teamwork regulation in the new human ecology of the digital transition during the COVID-19 pandemic. To achieve this objective, our research question is: what are the differences in personal goals, regulation strategies, and team challenges between engineering students working online and face-to-face in PBL challenges? 


\section{Materials and Methods}

\subsection{Research Context}

An engineering school at a university in Chile has a cohort of around 800 students. During their second year, fifty of these students enroll in the engineering, design, and innovation major.

Because this major seeks motivated students with creative potential and leadership capacity to face the complex dilemmas of innovation and design-engineering, students have to go through an application process involving a portfolio, an essay, and their academic grades (see Appendix A for the application process).

The major in engineering, design, and innovation is interdisciplinary. This means that the courses are delivered by the engineering school and by the design school (see Appendix B for the major in engineering, design, and innovation curriculum). Table 1 presents the five courses delivered by the Design and Engineering Department, School of Engineering.

Table 1. Courses delivered by the Design and Engineering Department, School of Engineering.

\begin{tabular}{cccc}
\hline Course & Project-Based Learning & Team Work & Semester Offered \\
\hline Visual Thinking & Yes & Yes & Both \\
Anthro Design & Yes & Yes & Only second \\
Design and Systems & Yes & Yes & Both \\
Thinking Lab. & No & No & Both \\
Entrepreneurial Mindset & Yes & Yes & Both \\
Capstone & & &
\end{tabular}

As shown in Table 1, of the five courses delivered by the Design and Engineering Department, four are taught following a project-based learning methodology and involve teamwork. Because the study was conducted in the first semester of 2019 and the first semester of 2020, the course Anthro Design was not considered (see Appendix C for the summary of each course involved in the study).

\subsection{Instrument}

For the data collection process, an adapted version of the self-report questionnaire called Adaptive Instrument for Regulation of Emotions [40] was used. AIRE is designed to explore students' experiences of individual and socially shared learning regulation given specific team challenges and goals. This questionnaire is structured in 3 sections covering: (1) personal goals, (2) team challenges, and (3) regulation strategies (self and socially shared).

The personal goals section comprises an open question and 13 teamwork goals statements that learners have to grade. The open question, "What was your major goal regarding this group exercise?", allowed students to report their own goal. After answering this question, students had to grade the 13 statements in terms of how important they were to them personally on a four-point Likert scale (from 1 = "not very important to me" to $4=$ "a top priority for me"). Afterward, they were asked to select the first and the second most important goals and the least important one.

The team challenges sections consist of 12 team-related challenges (regarding coordination, collaborative learning, and interpersonal relationships). Participants were asked to evaluate each challenge on a five-point Likert scale (from $0=$ "did not happen" to $4=$ "it was a big challenge"). The students were then asked to select the two biggest challenges in their experience.

Finally, the regulation strategies section presents a list of self-regulating and socially-shared regulating actions based on the two specific challenges they selected in the previous section. In particular, a list of eight individual strategies and four group-level strategies were displayed. Students had to evaluate each strategy on a five-point Likert scale (from $0=$ "did not happen" to $4=$ "did happen a $\left.\operatorname{lot}^{\prime \prime}\right)$. Lastly, the students were asked to evaluate how satisfied they were with their teamwork on a four-point Likert scale (from $1=$ "not satisfied at all" to $4=$ "fully satisfied"). 


\subsection{Adaptation Process}

To adapt the original instrument to our particular context, the research team first translated the original questionnaire into Spanish. The translation process was done in a one-way forward translation process conducted by a bilingual translator and a Spanish-native translator [41]. After translating the survey, the researchers discussed each item for clarity and pertinence [42]. Finally, six cognitive interviews were conducted [43] with students to produce evidence of the survey's validity. These interviews used comprehension probes (e.g., "what does that phrase mean to you") to obtain usability feedback [43].

After the assessment with students and within the research team, some of the items that our students did not clearly understand were removed. This item selection process (purification process) was guided using judgmental criteria for content validity [44]. Appendix D presents the final selection of items in Spanish and English.

\subsection{Participants}

The participants in this study were the students that completed at least one of the three sections considered: personal goals, teams challenges, or regulation strategies. Table 2 presents the number of participants in each category.

Table 2. The number of participants by the cohort, including the different sections and the responses for each one.

\begin{tabular}{ccc}
\hline Sample & $\mathbf{2 0 1 9}$ & $\mathbf{2 0 2 0}$ \\
\hline Total students & 87 & 94 \\
Total responses & 30 & 80 \\
Personal goals section & 25 & 77 \\
Team challenges section & 21 & 77 \\
Regulation strategies section & 17 & 62 \\
\hline
\end{tabular}

As seen in Table 2, concerning the 2019 cohort, out of the 87 students enrolled in the courses, 30 answered the questionnaire. Applying the exclusion criterion, the personal goals section was completed by 25 participants, the teams challenges section by 21 , and the regulation strategies section by 17. Regarding the 2020 cohort, out of 94 students enrolled in the courses, 80 of them answered the questionnaire. For this semester, 77 students completed the personal goals and the teams challenges sections, while 62 completed the regulation strategies section.

This study received ethics approval from the University Ethics Board. Students were asked to sign a consent form and were informed that they could leave the study at any time.

\subsection{Data Analysis Tools}

The comparison between the two groups of students (2019: face-to-face collaboration versus 2020: collaboration using online tools) was performed through a graphical analysis and statistical hypothesis tests.

To visually compare the results, mean score and standard deviation per question and group of students were plotted on a bar chart. Although this type of comparison is not conclusive, it may help to identify trends on item responses and (potential) similarities between groups.

The comparative analysis of the mean score per question and the group of students could also be made using statistical hypothesis tests. In general, an independent t-test could be applied [45]. However, it is worth noting that the responses were ordinal (on a range of values from 0 to 4), and therefore the normality assumption required by the t-test was hardly met. As an alternative, nonparametric tests are preferred since they are less restrictive because they do not assume any underlying mathematical distribution [46]. In particular, the Mann-Whitney U-test was used here to analyze whether each group of students' median scores per question were statistically different. 
In addition, the Bonferroni correction was applied as a way to adjust the $p$-values, as multiple statistical tests can lead to an increase in false-positive rates (type 1 error) [47].

All analyses were applied to personal goals, team challenges, and self-regulated and socially-regulated strategies by question and groups of students.

\section{Results}

The main objective of this study was to compare the response patterns in questions related to personal goals, team challenges, and self-regulated and socially-regulated strategies by two groups of students (2019: face-to-face collaboration versus 2020: collaboration using online tools).

Figure 1 shows the mean scores in each section of the adapted AIRE questionnaire. The behavior of the responses follows a similar pattern in both groups, in which, in most cases, the mean scores were relatively close, or at least the variability of responses was largely intersected. This means that there were no major differences between both groups of students. However, in a few cases, the differences were quite clear, for example, in questions 9, 10, and 12 of team challenges (see Figure 1b). For these three questions, the mean score of students who performed face-to-face activities (2019) was noticeably higher than those who used online tools (2020).

Graphical analysis is usually subjective, and therefore it is also necessary to use more robust statistical tools, such as hypothesis testing. Hence, the nonparametric Mann-Whitney U-test was applied to compare the median scores of each group of students by question (see Section 3.5 for more details about this statistical test).

Table 3 presents the $p$-values from the Mann-Whitney U-test with Bonferroni's correction. Corroborating and complementing the graphical analysis, the questions 9, 10, and 12 of team challenges and question 2 of self-regulated strategies were significantly different between groups of students. For question 2 of self-regulated strategies, the group that performed activities using online tools had a significantly higher mean score.

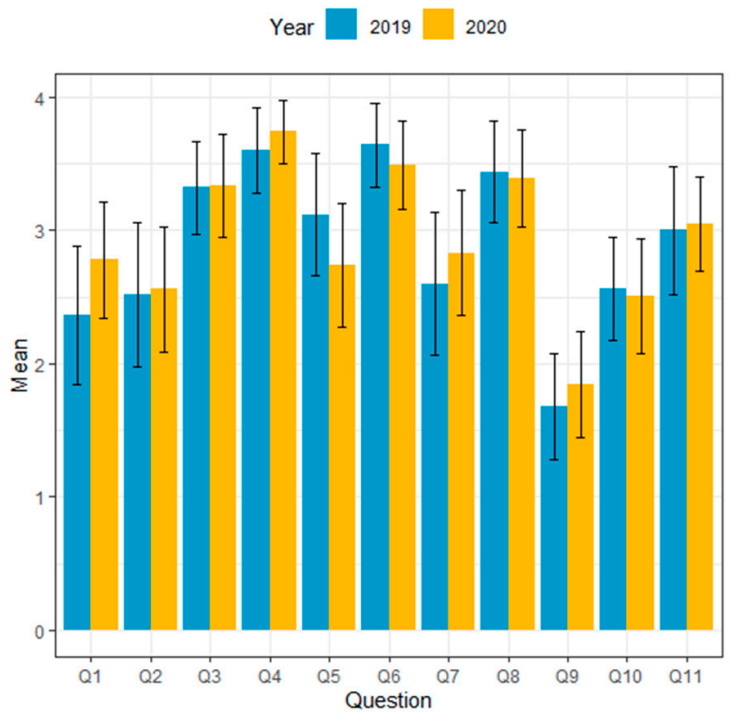

(a)

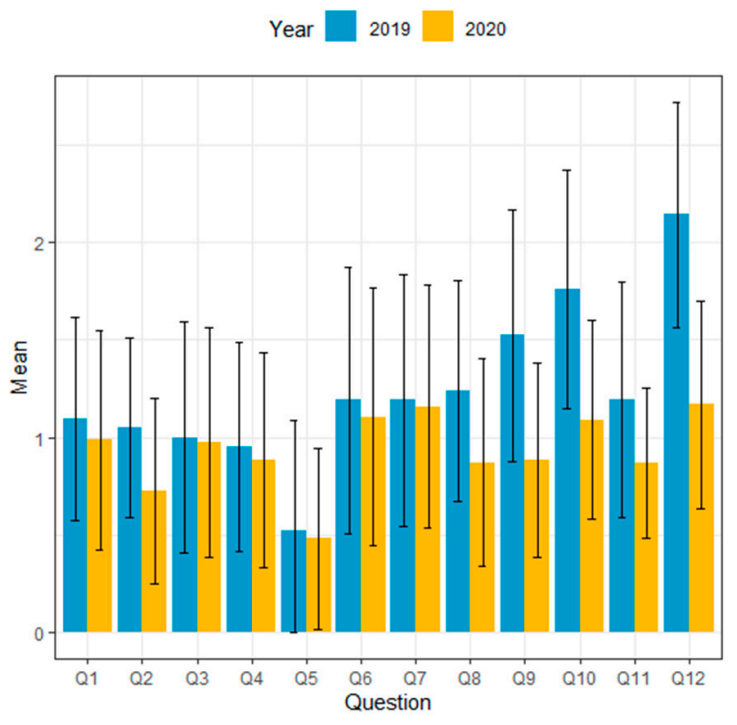

(b)

Figure 1. Cont. 


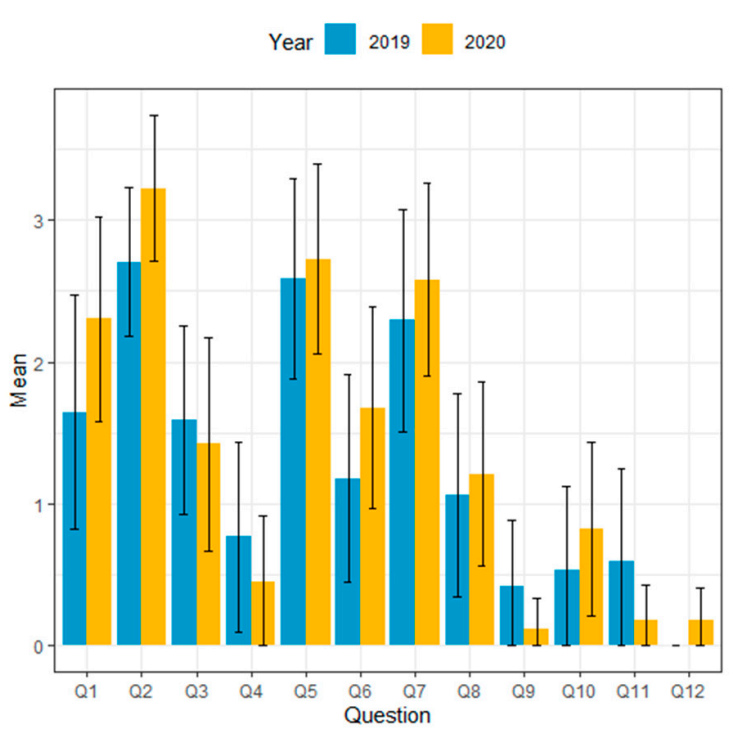

(c)

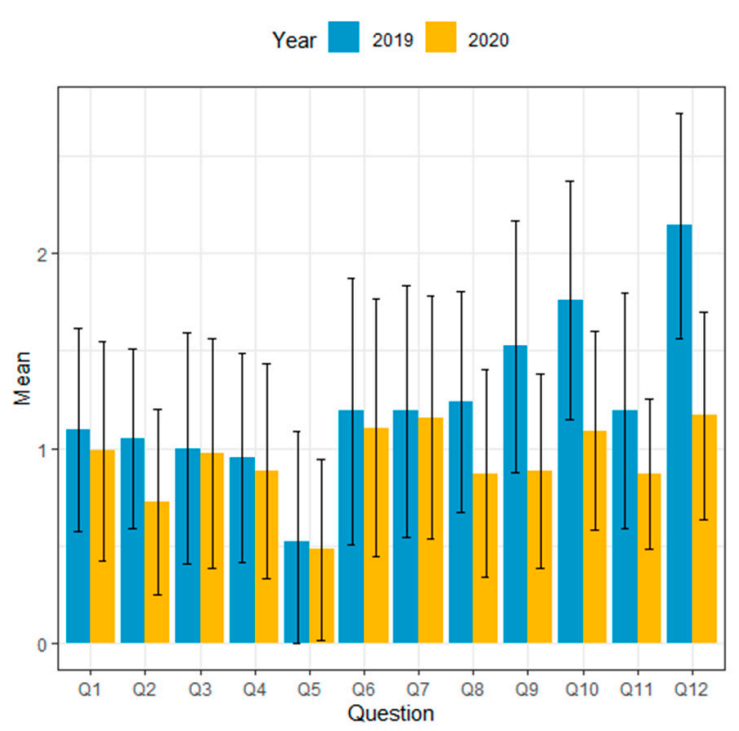

(d)

Figure 1. Mean score with half a standard deviation by groups of students (2019: face-to-face collaboration versus 2020: collaboration using online tools) for questions related to (a) personal goals, (b) team challenges, and (c) self-regulated and (d) socially—regulated strategies.

Table 3. $p$-values when applying the Mann-Whitney U-test with Bonferroni's correction by question. Null hypothesis: the median scores of the two groups of students (2019: face-to-face collaboration versus 2020: collaboration using online tools) are equal.

\begin{tabular}{ccccc}
\hline Question & Personal Goals & Team Challenges & Self-Regulated Strategies & Socially-Regulated Strategies \\
\hline Q1 & 0.0704 & 0.4891 & 0.1347 & 0.8214 \\
Q2 & 0.7575 & 0.0834 & $0.0361^{*}$ & 0.2154 \\
Q3 & 0.7549 & 0.8934 & 0.4911 & 0.7787 \\
Q4 & 0.3890 & 0.7306 & 0.5798 & 0.4422 \\
Q5 & 0.0765 & 0.9770 & 0.7187 & 0.1398 \\
Q6 & 0.2673 & 0.7901 & 0.1491 & 0.9851 \\
Q7 & 0.3718 & 0.8988 & 0.5691 & - \\
Q8 & 0.6801 & 0.1700 & 0.5254 & - \\
Q9 & 0.3132 & $0.0216^{*}$ & 0.2099 & - \\
Q10 & 0.8253 & $0.0181^{*}$ & 0.2722 & - \\
Q11 & 0.9565 & 0.4418 & 0.2473 & - \\
Q12 & - & $0.0007^{*}$ & 0.0999 & - \\
\hline
\end{tabular}

* There are significant differences considering a significance level of $5 \%$.

\section{Discussion}

In the context of an established interest in teamwork in engineering education research and practice, both as a learning outcome and as a teaching strategy, our study sought to explore how teamwork is affected by the digital transition during the COVID-19 crisis [10]. It is noted that the COVID-19 crisis provides a new scenario for online vs. face-to-face learning comparisons, given the fact that digitalization occurred in all systemic/ecological levels [38,39] and not just at the course level. In this new context, the "equivalency" degree [29] between those two modalities might be higher, as digital learning is more consistent with the new characteristics of the student's ecological environment, or it could be lower due to the greatest difference between the new and the preCOVID environment.

Based on the framework of socially—shared regulation of learning [12,24], this study describes the teamwork experiences of students in two semesters of PBL courses in a Chilean school of engineering. In that context, our study explored the following question: what are the differences in personal goals, regulation strategies, and team challenges between engineering students working online and face-to-face in PBL challenges? 
Overall, our answer is not many. Our findings through the adapted AIRE Questionnaire [40] show that most personal goals, team challenges, and regulation strategies are not significantly different among the two cohorts of students (see Table 3). These results provide supporting evidence for the "equivalency theory" [29] of digital learning. This evidence is consistent with previous studies in the field [32,33].

The results of this study contrast with previous research on the topic that reported less student satisfaction [32,35] more communication challenges [36] in online teamwork. This may indicate that the adaptation towards a digitalized life, not only a digital course, plays an important role as a mediator between online learning and teamwork outcomes. Nonetheless, the present study does not provide a clear answer for that hypothesis, and future research is needed to elucidate the specific impact of this mediation effect. Other hypotheses may be considered, for instance, the fact that newer generations are more digital-native [48] or cultural differences in e-learning adoption [49]. Probably, the effectiveness of educational teamwork strategies and the quality of teamwork learning are more complex, situated, and dialectical phenomena that will not allow for such direct and mechanical explanations as the one presented in the equivalency theory. As stated in the introduction, these courses were forcefully transformed into an online modality for health and social reasons. These conditions did likely affect time loads, teacher expectations, and students' dispositions towards teamwork in ways that could not be fully captured under the thesis of equivalency.

Although these findings support the idea that online and face-to-face learning yield similar teamwork outcomes, our study does provide some nuance regarding specific differences between modalities. In particular, this study identifies three challenges and one regulation strategy that was significantly less prevalent in the course's online version. The results of challenge Q12 ("We had different personal life circumstances or family/study and work commitments") seem expectable in the sense that all students were sharing similar experiences due to the confinement policies that forced them to stay at home all the time. Additionally, the COVID-19 crisis can be interpreted as a shared personal circumstance [50].

The results of challenge Q9 ("Some people were easily distracted") indicates that students working on online courses are perceived as being more focused on the task. This is consistent with the results on challenge Q10 ("Our ideas about what we should do were not the same") and strategy Q2 ("I tried to act more flexible") as they would indicate that online students sought to accommodate or give in to others opinion and that resulted in less perceived distractions.

Students may perceive this increased "efficiency" as a gain of the digital transition; however, this perception is not in line with current educational research. Theory and empirical research show that task conflict (disagreements about the team task) [27]—such as Q10 - is key to foster team performance and especially group creativity [16,51-53]. As described by classic constructivist theories of learning, cognitive conflict is a prerequisite for higher-order learning [54]. This is especially the case in the context of innovation-driven teams where creativity and divergence are valued [16]. In this sense, our observation based on the findings, far from encouraging the apparent changes in teamwork dynamics, points out its potential risks. As asserted by Garratt-Reed, Roberts, and Heritage [32], the individualization of the team's division of labor in digital learning may have negative consequences for the overall learning experience.

A decrease in the prevalence of task conflict (as shown in Q10) may be produced by changes in the learning dynamics that produced fewer task disagreements (e.g., the task was clearer or the students were more prepared) or by changes in the team's strategies. The results from strategy Q2 ("I tried to act more flexible") is an indication of the latter. Previous research shows that giving in to others' opinions or becoming too accommodating are markers of conflict avoidance [55]. Additionally, the results from challenge Q9 ("Some people were easily distracted") fit within this interpretation, as team conflict typically has a negative connotation [56] and is perceived as a distraction from the task at hand [57].

For these reasons, it is concluded that the lower prevalence of task conflicts and the increase of individual flexibilization are indicative of less group deliberation and the kind of team conflict 
that is necessary for innovation to take place. Future research may further explore this idea by investigating qualitative perceptions of conflict and conflict management during online teamwork projects. Future research may also explore if online collaboration, when allowing for conflict avoidance, tends to produce a less creative performance, as portrayed in the literature. Additionally, it is important that future studies explore issues of team composition (especially regarding gender or race minorities) and how digitalization at different school levels (course level, major level, and curriculum level) impacts the teamwork experience of students.

Finally, this research presents a series of limitations that should be considered in future interpretations of these findings. From a statistical point of view, this study has two important limitations: unbalanced data and a relatively small sample size. Both of them restrict the generalizability of the results and decrease the statistical power. The nonparametric methodology employed (Mann-Whitney U-test) mitigates the impact of the results when the sample is small and unbalanced. However, other sample biases, such as self-selection bias, may still have an impact on the interpretability of this study. In this sense, the conclusions made in this study have to be carefully considered, especially when seeking to generalize to other populations. On the other hand, the context of the COVID-19 pandemic will undoubtedly affect the extrapolations of this research in a non-pandemic future. As a research team, we expected that the pandemic would produce a greater prevalence of challenges in students compared to the 2019 cohort, which did not happen. Furthermore, this study does not provide evidence on how different student's identities (such as gender and race) affect teamwork experience. Having a more in-depth analysis at the individual level is crucial to generalize these results to other populations. Considering these limitations, it is important to emphasize that our more general conclusions are of more importance than specific results in each item.

\section{Conclusions}

This study compared two generations of engineering students that participated in the same PBL courses in two different modalities: online and face-to-face. According to these research findings, the prevalence of personal goals, team challenges, and regulation strategies was comparable among the two cohorts. This evidence supports the idea of a potential equivalency of online learning versus face- - to-face. However, this study also notes that the effects of the COVID-19 pandemic forced the whole student's life to an online transition, thus the overall ecological consistency between online activities should be considered. Our results suggest that online students tend to report fewer task conflicts, team distractions, and more personal flexibility despite the overall equivalency of modalities. These results are interpreted as indicative of potential conflict avoidance that could be detrimental to the learning process, as task conflict is a known predictor of creativity and performance in team projects. Ultimately, this research shows that online and face-to-face PBL courses may yield similar results. Still, more attention is needed regarding the emergence and the management of conflict in online teams.

Author Contributions: Conceptualization, J.G. and C.C.; methodology, D.A., J.G., C.C., and C.M.; formal analysis, D.A., J.G., and U.D.; data curation, J.G., C.C., and C.M.; writing-original draft preparation, J.G., C.C., and D.A.; writing-review and editing, J.G., C.C., and C.M. All authors have read and agreed to the published version of the manuscript.

Funding: This research received no external funding.

Acknowledgments: We would like to thank the team of professors who taught the courses and the students that participated in them.

Conflicts of Interest: The authors declare no conflict of interest.

\section{Appendix A}

Engineering, Design, and Innovation Major Application Process. 


\section{Appendix A.1 Essay}

Students must answer the following question in the form of an essay, which will allow us to understand what the student knows and thinks about Engineering, Design, and Innovation.

Considering the current Chilean reality, what aspects do you consider important in the design process that will contribute to your training as an engineer? Consider your past and future experiences.

For the commission of this process, it is important to understand how the student impacts the world around him, his immediate world, and the one that is not so much. It is relevant that the student's point of view is distinguishable and that it is not diluted in formalities or bottomless words.

The essay must be delivered according to the following format:

- Digital in PDF format.

- The answer must have a minimum of 500 words and a maximum of 700 words.

- 1.5 line spacing

- Free font and size.

- It must include name, surname, email, and number of the student.

\section{Appendix A.2 Portfolio or Cases}

Each student must submit a portfolio with a minimum of 3 pieces that represent the activities, interests, and creativity of the applicant inside and outside the classroom; the applicant may choose the combination of portfolio pieces that best represents him. Technical excellence is not sought, nor is the student an expert in specific technologies or knowledge in the area of engineering, design, or innovation. This portfolio seeks to show the student's potential in terms of leadership, passion, project intention, and commitment to an idea or project that the student highlights their process, mistakes, strategic way of thinking, and leadership. It should be noted that if the student decides to show a mixture of cases and projects, he must indicate which are cases and which are projects.

\section{Appendix B}

Engineering, Design, and Innovation Major Curriculum.

\section{DESIGN, ENGINEERING, AND INNOVATION MAJOR} CURRICULUM
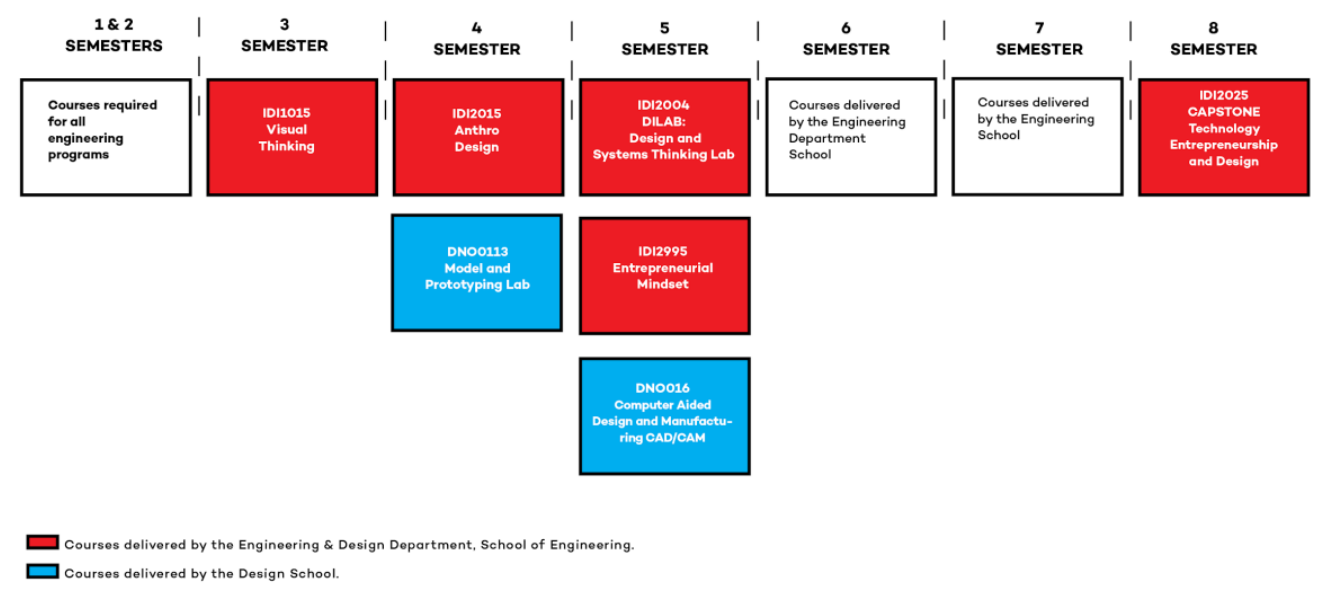

\section{Appendix C}

Courses Summary Description. 


\begin{tabular}{|c|c|c|c|}
\hline Course & Visual Thinking & Design and System Lab & $\begin{array}{l}\text { Major Engineering, Design, } \\
\text { and Innovation Capstone }\end{array}$ \\
\hline Teaching Methods & $\begin{array}{l}\text { Project-based Learning } \\
\text { Teamwork } \\
\text { 1. Introduction to Visual } \\
\text { Thinking. }\end{array}$ & $\begin{array}{l}\text { Project-based Learning } \\
\text { Teamwork }\end{array}$ & $\begin{array}{l}\text { Project-based Learning } \\
\text { Teamwork }\end{array}$ \\
\hline Course content & $\begin{array}{l}\text { 2. Misleading and False } \\
\text { information. } \\
\text { 3. What is knowledge?. } \\
\text { Project Formulation. } \\
\text { 4. Self-data tracking. } \\
\text { 5. Data visualization } \\
\text { process. Perception and } \\
\text { its implications for } \\
\text { design. } \\
\text { 6.Usability, Affordance } \\
\text { and conceptual models. } \\
\text { Narrative Rhetoric. } \\
\text { 7.Data representation } \\
\text { architecture. Physical } \\
\text { Visualizations. New } \\
\text { Media and Media Arts }\end{array}$ & $\begin{array}{l}\text { 1. Application of } \\
\text { anthropology design } \\
\text { tools for the study of the } \\
\text { human interface learned } \\
\text { in the IDI2015 course. } \\
\text { 2. Visual work tools for } \\
\text { the generation of } \\
\text { narratives, analysis and } \\
\text { reduction of information. } \\
\text { 3. Engineering design } \\
\text { process, digital } \\
\text { prototyping and testing. } \\
\text { 04. Teamwork and } \\
\text { negotiation techniques. }\end{array}$ & $\begin{array}{l}\text { 1. Basic characteristics of a } \\
\text { circular economy. } \\
\text { 2. Reuse, reconditioning, } \\
\text { re-manufacturing and recycling } \\
\text { processes. } \\
\text { 3. Design of sustainable } \\
\text { product-service systems. } \\
\text { 4. Alternative business models } \\
\text { for the circular economy. } \\
\text { 5. Design, innovation and } \\
\text { entrepreneurship for } \\
\text { sustainability. }\end{array}$ \\
\hline Learning Outcomes & $\begin{array}{l}\text { 1. Discuss and give } \\
\text { opinions about the } \\
\text { theories, methods and } \\
\text { tools that support the } \\
\text { reasoning behind } \\
\text { visualization. } \\
\text { 2. Select, apply and } \\
\text { adapt methods and } \\
\text { technologies for data } \\
\text { visualization addressed } \\
\text { in classes. } \\
\text { 3. Devise, plan, program } \\
\text { and build creative } \\
\text { designs that display } \\
\text { visual content. }\end{array}$ & $\begin{array}{l}\text { 1. Identify cultural } \\
\text { particularities through } \\
\text { the observation and } \\
\text { analysis of human } \\
\text { behavior selecting, } \\
\text { applying and adapting } \\
\text { the methods seen in } \\
\text { classes. } \\
\text { 2. Identify and define } \\
\text { design opportunities } \\
\text { through the tools to face } \\
\text { ambiguous problems } \\
\text { and "imperfect" } \\
\text { knowledge [that is not } \\
\text { controllable] provided by } \\
\text { a counterpart. } \\
\text { 3. Apply visual tools to } \\
\text { create short narratives } \\
\text { and objects that enhance } \\
\text { communication between } \\
\text { groups of diverse } \\
\text { idiosyncrasies. } \\
\text { 4. Devise and build } \\
\text { rapid test prototypes. } \\
\text { 5. Reflect on their own } \\
\text { ideation processes, their } \\
\text { role and collaboration } \\
\text { skills in a work team and } \\
\text { the counterpart. } \\
6 . \text { Lead and manage } \\
\text { projects through the } \\
\text { development of personal } \\
\text { organization skills, } \\
\text { organization of team } \\
\text { times, completion of } \\
\text { tasks and deliverables } \\
\text { for the counterpart and } \\
\text { the teacher. } \\
\text { tions }\end{array}$ & $\begin{array}{l}\text { 1. Identify the main } \\
\text { characteristics of a circular } \\
\text { economy, production and } \\
\text { consumption models } \\
\text { sustainable. } \\
\text { 2. Design products taking into } \\
\text { account user requirements and } \\
\text { the characteristics of models of } \\
\text { production and consumption in } \\
\text { a circular economy. } \\
\text { 3. Design services and } \\
\text { experiences that meet user } \\
\text { requirements and follow a } \\
\text { circular logic. } \\
\text { 4. Design sustainable product } \\
\text { and service systems for the } \\
\text { circular economy taking into } \\
\text { account the user requirements } \\
\text { and social, environmental and } \\
\text { economic aspects of the } \\
\text { situation. } \\
\text { 5. Critically evaluate projects } \\
\text { from a triple impact perspective: } \\
\text { socially, economically and } \\
\text { sustainably. } \\
\text { 6. Communicate in an } \\
\text { appropriate and attractive way } \\
\text { the value proposition of a } \\
\text { solution, highlighting its } \\
\text { potential in } \\
\text { terms of its contribution to a } \\
\text { more sustainable society. }\end{array}$ \\
\hline
\end{tabular}




\begin{tabular}{|c|c|c|c|}
\hline Course & Visual Thinking & Design and System Lab & $\begin{array}{l}\text { Major Engineering, Design, } \\
\text { and Innovation Capstone }\end{array}$ \\
\hline Assessment Methods & $\begin{array}{l}\text { 1. One individual project. } \\
\text { 2. Two team projects. } \\
\text { 3. Peer assessment after } \\
\text { each of the team project } \\
\text { The professor and } \\
\text { teacher assistant: During } \\
\text { the semester, the } \\
\text { professor and TA } \\
\text { assesses the process and } \\
\text { outcome. }\end{array}$ & $\begin{array}{l}\text { The course includes the } \\
\text { periodic performance of } \\
\text { individual assessed } \\
\text { activities (mini } \\
\text { challenges) and group } \\
\text { tasks. During the } \\
\text { semester students will } \\
\text { carry out an applied } \\
\text { project (great challenge) } \\
\text { using the techniques } \\
\text { learned in class. This } \\
\text { project } \\
\text { will be evaluated } \\
\text { regarding the satisfaction } \\
\text { of the counterpart and } \\
\text { the fulfillment of the } \\
\text { pre-defined academic } \\
\text { objectives } \\
\text { in the syllable. The } \\
\text { "great challenge" will } \\
\text { allow learning-by doing, } \\
\text { applying teamwork } \\
\text { techniques, visual } \\
\text { thinking, } \\
\text { digital modeling, study } \\
\text { of the human interface } \\
\text { and the design of a } \\
\text { digital prototype. There } \\
\text { will be peer evaluation. }\end{array}$ & $\begin{array}{l}\text { The course includes individual } \\
\text { and group tasks, and two } \\
\text { projects applied in groups with } \\
\text { their respective presentations } \\
\text { and } \\
\text { orders. The tasks and projects } \\
\text { will be evaluated regarding the } \\
\text { fulfillment of the defined } \\
\text { academic objectives } \\
\text { for each order. } \\
\text { The student must have group } \\
\text { and individual grades above } 4.0 \\
\text { to pass the course. } \\
\text { Non-delivery or delivery out of } \\
\text { time will imply a } 1.0 \text { in that } \\
\text { evaluation. } \\
\text { Individual Tasks }(15 \%) \\
\text { Group Tasks }(25 \%) \\
\text { Project } 1(20 \%) \\
\text { Project } 2(40 \%)\end{array}$ \\
\hline
\end{tabular}

\section{Appendix D}

Table A1. The final selection of personal goals item in Spanish and English.

\begin{tabular}{crr}
\hline Question & Personal Goals & Metas Personales \\
\hline Q1 & Get the highest possible mark, ideally a high distinction. & Obtener la nota más alta posible, idealmente un 7. \\
Q2 & Make sure my grade is not going to be low because of the group. & Asegurarme de no tener una mala nota debido a mi grupo. \\
Q3 & Learn as much as possible from others. & Aprender tanto como sea posible de los demás compañeros. \\
Q4 & Get new ideas from the group. & Obtener nuevas ideas del grupo de trabajo. \\
Q5 & Avoid being stressed. & Evitar estar estresado. \\
Q6 & Not let the group down. & No defraudar a mi equipo. \\
Q7 & Make new friends, socialise with other students. & Hacer nuevos amigos, relacionarme con otros estudiantes. \\
Q8 & Take personal responsibility for the work. & Asumir responsabilidad personal por el trabajo. \\
Q9 & Make sure I did not do more than others. & Asegurarme de no hacer mucho más que el resto del equipo. \\
Q10 & Make sure everyone in the group contributed equally. & Asegurarme de que todo el grupo haya \\
& contribuido equitativamente.
\end{tabular}

Table A2. The final selection of team challenges item in Spanish and English.

\begin{tabular}{|c|c|c|}
\hline Question & Team Challenges & Desafíos de Equipo \\
\hline Q1 & Our goals for the project were different. & $\begin{array}{l}\text { Nuestros objetivos académicos para el } \\
\text { proyecto eran diferentes. }\end{array}$ \\
\hline Q2 & We had different priorities. & Tuvimos prioridades sociales diferentes. \\
\hline Q3 & We seemed to have incompatible styles of working. & Parecíamos tener estilos de trabajo incompatibles. \\
\hline Q4 & We seemed to have different styles of interacting. & Parecíamos tener estilos diferentes de relacionarnos. \\
\hline Q5 & People in our group did not connect very well with one another. & Personas en nuestro grupo no conectaron bien entre sí. \\
\hline Q6 & One/some people were not fully committed to the group project. & $\begin{array}{l}\text { Uno/algunas personas no se comprometieron } \\
\text { plenamente al proyecto de grupo. }\end{array}$ \\
\hline Q7 & People had very different standards of work. & Las personas tenían estándares muy diferentes de trabajo. \\
\hline Q8 & Group members were not equal. & No todos tuvieron el mismo peso en las decisiones grupales. \\
\hline Q9 & Some people were easily distracted. & Algunas personas se distraían fácilmente. \\
\hline Q10 & Our ideas about what we should do were not the same. & $\begin{array}{l}\text { Nuestras ideas sobre qué tendríamos que } \\
\text { hacer no fueron iguales. }\end{array}$ \\
\hline
\end{tabular}


Table A2. Cont.

\begin{tabular}{ccc}
\hline Question & Team Challenges & Desafíos de Equipo \\
\hline Q11 & We differed in our understanding of the concepts/task. & $\begin{array}{c}\text { Diferimos en nuestro entendimiento } \\
\text { de la tarea/los conceptos. }\end{array}$ \\
Q12 & We had different personal life circumstances or family/study and \\
work commitments. & $\begin{array}{c}\text { Tuvimos circunstancias de vida o compromisos previos de } \\
\text { trabajo, estudio o familiares muy diferentes. } \\
\text { Esto dificultó el trabajo. }\end{array}$ \\
\hline
\end{tabular}

Table A3. The final selection of self-regulated strategies item in Spanish and English.

\begin{tabular}{|c|c|c|}
\hline Question & Self-Regulated Strategies & Estrategias Autorreguladas \\
\hline Q1 & I convince myself that it could actually be a good thing. & $\begin{array}{l}\text { Me convencí a mi mismo de que podría ser algo } \\
\text { positivo para el proyecto. }\end{array}$ \\
\hline Q2 & I tried to act more flexible. & Traté de ser más flexible. \\
\hline Q3 & $\begin{array}{l}\text { I told the others that we needed to accept that some people were } \\
\text { prepared to put in more work than others. }\end{array}$ & $\begin{array}{l}\text { Le dije a los otros que debemos aceptar que algunas } \\
\text { personas están preparadas para hacer más trabajo que otras. }\end{array}$ \\
\hline Q4 & $\begin{array}{c}\text { I only interacted with team members who had the same } \\
\text { priorities as me. }\end{array}$ & $\begin{array}{l}\text { Sólo interactué con los miembros del equipo que tenían las } \\
\text { mismas prioridades que yo. }\end{array}$ \\
\hline Q5 & $\begin{array}{l}\text { I tried to understand that the others were not simply trying to be } \\
\text { difficult but they had different goals. }\end{array}$ & $\begin{array}{l}\text { Traté de entender que los otros no estaban simplemente } \\
\text { tratando de ser difíciles sino que tenían otras metas. }\end{array}$ \\
\hline Q6 & $\begin{array}{l}\text { I told the others we needed to be more flexible in order to find a } \\
\text { compromise/solution for the situation. }\end{array}$ & $\begin{array}{l}\text { Le dije a los otros que necesitábamos ser más flexibles para } \\
\text { encontrar una solución o acuerdo para esta situación. }\end{array}$ \\
\hline Q7 & $\begin{array}{l}\text { I tried to accept the situation and realise that some people were } \\
\text { prepared to put in more work than others. }\end{array}$ & $\begin{array}{l}\text { Traté de aceptar la situación dándome cuenta que hay } \\
\text { personas más preparadas para aportar que otras. }\end{array}$ \\
\hline Q8 & $\begin{array}{c}\text { I tried to explain to others that we needed to understand } \\
\text { different goals. }\end{array}$ & $\begin{array}{l}\text { Traté explicarles a los otros que tenemos } \\
\text { que entender diferentes metas. }\end{array}$ \\
\hline Q9 & I told someone that it would be better if he doesn't involve much. & Le dije a alguien que sería mejor si no se mete mucho. \\
\hline Q10 & $\begin{array}{l}\text { I tried to convince someone that the others were not simply } \\
\text { trying to be difficult and we can solve the situation. }\end{array}$ & $\begin{array}{l}\text { Traté de convencer a alguien que los otros no estaban } \\
\text { simplemente tratando de ser difíciles y que podemos } \\
\text { solucionar la situación. }\end{array}$ \\
\hline Q11 & I told someone to change their goals or face the consequences. & $\begin{array}{l}\text { Le dije a alguien que cambiara sus } \\
\text { metas o enfrentara las consecuencias. }\end{array}$ \\
\hline Q12 & I decided to contribute as little as possible. & Decidí sólo contribuir lo mínimo posible. \\
\hline
\end{tabular}

Table A4. The final selection of socially-regulated strategies item in Spanish and English.

\begin{tabular}{|c|c|c|}
\hline Question & Socially-Regulated Strategies & Estrategias Socialmente Reguladas \\
\hline Q1 & $\begin{array}{l}\text { We understood that we have to reconcile our goals } \\
\text { closer to one another. }\end{array}$ & $\begin{array}{l}\text { Nos dimos cuenta que teníamos que } \\
\text { reconciliar nuestras metas y } \\
\text { acercarlas entre nosotros. }\end{array}$ \\
\hline Q2 & We only try to achieve the majority goal of the group. & Intentamos sólo lograr la meta de la mayoría del grupo. \\
\hline Q3 & $\begin{array}{l}\text { We solve the situation by compromising to accommodate } \\
\text { everyone's goals. }\end{array}$ & $\begin{array}{c}\text { Resolvimos la situación comprometiéndonos a acomodar las } \\
\text { metas de todos. }\end{array}$ \\
\hline Q4 & $\begin{array}{l}\text { We decided to solve the situation together and find a way to } \\
\text { complete our work in the best possible conditions. }\end{array}$ & $\begin{array}{c}\text { Decidimos solucionar la situación juntos y encontrar una } \\
\text { manera de completar nuestro trabajo en las mejores } \\
\text { condiciones posibles. }\end{array}$ \\
\hline Q5 & $\begin{array}{l}\text { We resolved the situation by agreeing that some people weren't } \\
\text { going to contribute much. }\end{array}$ & $\begin{array}{c}\text { Resolvimos la situación al estar de acuerdo que algunas } \\
\text { personas no iban a contribuir mucho. }\end{array}$ \\
\hline Q6 & $\begin{array}{l}\text { We accepted that different members have different goals and we } \\
\text { organised our working according to that. }\end{array}$ & $\begin{array}{c}\text { Aceptamos que los diferentes miembros tenian metas } \\
\text { diferentes y que teníamos que organizar nuestro trabajo de } \\
\text { acuerdo a eso. }\end{array}$ \\
\hline
\end{tabular}

\section{References}

1. O’Neill, T.A.; Deacon, A.; Larson, N.L.; Hoffart, G.C.; Brennan, R.W.; Eggermont, M.; Rosehart, W. Life-long learning, conscientious disposition, and longitudinal measures of academic engagement in engineering design teamwork. Learn. Individ. Differ. 2015, 39, 124-131. [CrossRef]

2. Prados, J.W.; Peterson, G.D.; Lattuca, L.R. Quality assurance of engineering education through accreditation: The impact of engineering criteria 2000 and its global influence. J. Eng. Educ. 2005, 94, 165-184. [CrossRef]

3. Passow, H.J.; Passow, C.H. What competencies should undergraduate engineering programs emphasize? A systematic review. J. Eng. Educ. 2017, 106, 475-526. [CrossRef]

4. Prados, J. Abet Engineering Criteria 2000: How we got there and why. In Proceedings of the ASEE Annual Conference, Milwaukee, WI, USA, 15-18 June 1997. [CrossRef]

5. Perusich, K.; Davis, B.; Taylor, K. Teamwork and ABET Review: A Template for Assessment. In Technological Developments in Education and Automation; Iskander, M., Kapila, V.K.M., Karim, M.A., Eds.; Springer: Dordrecht, The Netherlands, 2010; pp. 349-353.

6. Mills, H.; Treagust, D. Engineering Education. Is problem-based or project-based learning the answer? Australas. J. Eng. Educ. 2003, 3, 2-16. 
7. Reis, A.C.B.; Barbalho, S.C.M.; Zanette, A.C.D. A bibliometric and classification study of project-based learning in engineering education. Production 2017, 27. [CrossRef]

8. Froyd, J.E. The engineering education coalitions program. In Educating the Engineer of 2020: Adapting Engineering Education to the New Century; National Academy of Engineering, Ed.; National Academies Press: Washington, DC, USA, 2005.

9. Borrego, M.; Karlin, J.; McNair, L.D.; Beddoes, K. Team effectiveness theory from industrial and organizational psychology applied to engineering student project teams: A research review. J. Eng. Educ. 2013, 102, 472-512. [CrossRef]

10. Crawford, J.; Butler-Henderson, K.; Rudolph, J.; Malkawi, B.; Glowatz, M.; Burton, R.; Magni, P.; Lam, S. COVID-19: 20 countries' higher education intra-period digital pedagogy responses. J. Appl. Learn. Teach. 2020, 3. [CrossRef]

11. Hadwin, A.; Oshige, M. Self-regulation, coregulation, and socially shared regulation: Exploring perspectives of social in self-regulated learning theory. Teach. Coll. Rec. 2011, 113, 240-264.

12. Panadero, E.; Järvelä, S. Socially shared regulation of learning: A review. Eur. Psychol. 2015, 20, 190-203. [CrossRef]

13. Guerra, A.; Ulseth, R.; Kolmos, A. PBL in Engineering Education: International Perspectives on Curriculum Change; Sense Publishers: Rotterdam, The Netherlands, 2017.

14. Chen, J.; Kolmos, A.; Du, X. Forms of implementation and challenges of PBL in engineering education: A review of literature. Eur. J. Eng. Educ. 2020, 1-26. [CrossRef]

15. Bani-Hani, E.; Al Shalabi, A.; Alkhatib, F.; Eilaghi, A.; Sedaghat, A. Factors affecting the team formation and work in project based learning (PBL) for multidisciplinary engineering subjects. J. Probl. Based Learn. High. Educ. 2018, 6, 136-143. [CrossRef]

16. Miranda, C.; Goñi, J.; Hilliger, I. Orchestrating conflict in teams with the use of boundary objects and trading zones in innovation-driven engineering design projects. Int. J. Technol. Des. Educ. 2019. [CrossRef]

17. Chowdhury, T.; Murzi, H. Literature review: Exploring teamwork in engineering education. In Proceedings of the Conference: Research in Engineering Education Symposium, Cape Town, South Africa, 10-12 July 2019; pp. 244-252.

18. Brunhaver, S.R.; Korte, R.F.; Barley, S.R.; Sheppard, S.D. Bridging the Gaps between Engineering Education and Practice. In U.S. Engineering in a Global Economy; Freeman, R.B., Salzman, H., Eds.; University of Chicago Press: Chicago, IL, USA, 2018; pp. 129-164.

19. Matusovich, H.M.; Paretti, M.C.; Motto, A.M.; Cross, K.J. Understanding faculty and student beliefs about teamwork \& communication skills. In Proceedings of the 119th ASEE Annual Conference and Exposition, San Antonio, TX, USA, 10-13 June 2012; American Society for Engineering Education: Washington, DC, USA, 2012.

20. Pintrich, P.R. The Role of Goal Orientation in Self-Regulated Learning. In Handbook of Self-Regulation; Boekaerts, M., Pintrich, P.R., Zeidner, M., Eds.; Academic Press: San Diego, CA, USA, 2000; pp. 452-502.

21. Paoletti, J.; Bisbey, T.M.; Reyes, D.L.; Wettergreen, M.A.; Salas, E. A checklist to diagnose teamwork in engineering education. Int. J. Eng. Educ. 2020, 36, 365-377.

22. Järvenoja, H.; Järvelä, S. Emotion control in collaborative learning situations: Do students regulate emotions evoked by social challenges. Br. J. Educ. Psychol. 2009, 79, 463-481. [CrossRef]

23. Järvelä, S.; Järvenoja, H.; Malmberg, J. Capturing the dynamic and cyclical nature of regulation: Methodological Progress in understanding socially shared regulation in learning. Int. J. Comput. Collab. Learn. 2019, 14, 425-441. [CrossRef]

24. Hadwin, A.; Järvelä, S.; Miller, M. Self-Regulation, Co-Regulation, and Shared Regulation in Collaborative Learning Environments. In Handbook of Self-Regulation of Learning and Performance; Routledge: Abingdon-on-Thames, UK, 2017; pp. 83-106.

25. Järvelä, S.; Hadwin, A.F. New Frontiers: Regulating Learning in CSCL. Educ. Psychol. 2013, 48, 25-39. [CrossRef]

26. Järvenoja, H.; Näykki, P.; Törmänen, T. Emotional regulation in collaborative learning: When do higher education students activate group level regulation in the face of challenges? Stud. High. Educ. 2019, 44, 1747-1757. [CrossRef]

27. Turner, J.R. Team cognition conflict: A conceptual review identifying cognition conflict as a new team conflict construct. Perform. Improv. Q. 2016, 29, 145-167. [CrossRef]

28. Kaplan, A.; Maehr, M.L. The contributions and prospects of goal orientation theory. Educ. Psychol. Rev. 2007, 19, 141-184. [CrossRef]

29. Simonson, M. Equivalency theory and distance education. TechTrends 1999, 43, 5-8. [CrossRef] 
30. Simonson, M.; Schlosser, C.; Hanson, D. Theory and distance education: A new discussion. Am. J. Distance Educ. 1999, 13, 60-75. [CrossRef]

31. Simonson, M.; Smaldino, S.; Zvacek, S. Teaching and Learning at a Distance: Foundations of Distance Education, 6th ed.; Information Age Publishing: Charlotte, NC, USA, 2014.

32. Garratt-Reed, D.; Roberts, L.D.; Heritage, B. Grades, Student satisfaction and retention in online and face-to-face introductory psychology units: A test of equivalency theory. Front. Psychol. 2016, 7. [CrossRef] [PubMed]

33. Lapsley, R.; Kulik, B.; Moody, R.; Arbaugh, J.B. (Ben) Is identical really identical? An investigation of equivalency theory and online learning. J. Educ. Online 2008. [CrossRef]

34. Vigotsky, L. Thinking and Speech. In The Collected Works of L. S. Vygotsky; Rieber, R.W., Carton, A.S., Eds.; Plenum Press: New York, NY, USA, 1987; pp. 39-285.

35. Vance, K.; Kulturel-Konak, S.; Konak, A. Teamwork efficacy and attitude differences between online and face-to-face students. In Proceedings of the 2015 IEEE Integrated STEM Education Conference, Princeton, NJ, USA, 7 March 2015; pp. 246-251.

36. Lin, G.-Y. Scripts and mastery goal orientation in face-to-face versus computer-mediated collaborative learning: Influence on performance, affective and motivational outcomes, and social ability. Comput. Educ. 2020, 143, 103691. [CrossRef]

37. Worthman, C.M. The ecology of human development: Evolving models for cultural psychology. J. Cross. Cult. Psychol. 2010, 41, 546-562. [CrossRef]

38. Rosa, E.M.; Tudge, J. Urie Bronfenbrenner's theory of human development: Its evolution from ecology to bioecology. J. Fam. Theory Rev. 2013, 5, 243-258. [CrossRef]

39. Bronfenbrenner, U. The Ecology of Human Development: Experiments by Nature and Design; Harvard University Press: Cambridge, MA, USA, 1979.

40. Järvenoja, H.; Volet, S.; Järvelä, S. Regulation of emotions in socially challenging learning situations: An instrument to measure the adaptive and social nature of the regulation process. Educ. Psychol. 2013, 33, 31-58. [CrossRef]

41. Tsang, S.; Royse, C.; Terkawi, A. Guidelines for developing, translating, and validating a questionnaire in perioperative and pain medicine. Saudi J. Anaesth. 2017, 11, 80. [CrossRef]

42. Blair, J.; Czaja, R.F.; Blair, E.A. Designing Surveys: A Guide to Decisions and Procedures, 3rd ed.; SAGE Publications: Thousand Oaks, CA, USA, 2013.

43. Willis, G. Cognitive Interviewing in Survey Design: State of the Science and Future Directions. In The Palgrave Handbook of Survey Research; Springer International Publishing: Cham, Switzerland, 2018; pp. 103-107.

44. Wieland, A.; Durach, C.F.; Kembro, J.; Treiblmaier, H. Statistical and judgmental criteria for scale purification. Supply Chain Manag. Int. J. 2017, 22, 321-328. [CrossRef]

45. Gerald, B. A brief review of Independent, Dependent and One Sample t-test. Int. J. Appl. Math. Theor. Phys. 2018, 4, 50-54. [CrossRef]

46. Whitley, E.; Ball, J. Statistics review 6: Nonparametric methods. Crit. Care 2002, 6, 509-513. [CrossRef] [PubMed]

47. Armstrong, R.A. When to use the Bonferroni correction. Ophthalmic Physiol. Opt. 2014, 34, 502-508. [CrossRef] [PubMed]

48. Barak, M. Are digital natives open to change? Examining flexible thinking and resistance to change. Comput. Educ. 2018, 121, 115-123. [CrossRef]

49. Zhao, Y.; Wang, N.; Li, Y.; Zhou, R.; Li, S. Do cultural differences affect users' e-learning adoption? A meta-analysis. Br. J. Educ. Technol. 2020. [CrossRef]

50. Templeton, A.; Guven, S.T.; Hoerst, C.; Vestergren, S.; Davidson, L.; Ballentyne, S.; Madsen, H.; Choudhury, S. Inequalities and identity processes in crises: Recommendations for facilitating safe response to the COVID-19 pandemic. Br. J. Soc. Psychol. 2020, 59, 674-685. [CrossRef]

51. Bradley, B.H.; Anderson, H.J.; Baur, J.E.; Klotz, A.C. When conflict helps: Integrating evidence for beneficial conflict in groups and teams under three perspectives. Gr. Dyn. Theory, Res. Pract. 2015, 19, 243-272. [CrossRef]

52. Johnson, D.W.; Johnson, R.T. Energizing Learning: The Instructional Power of Conflict. Educ. Res. 2009, 38, 37-51. [CrossRef]

53. Lee, E.K.; Avgar, A.C.; Park, W.-W.; Choi, D. The dual effects of task conflict on team creativity. Int. J. Confl. Manag. 2019, 30, 132-154. [CrossRef]

54. Piaget, J. Piaget's Theory. In Piaget and His School; Springer: Berlin/Heidelberg, Germany, 1976; pp. 11-23. 
55. Roloff, M.E.; Liu, E. Conflict Avoidance. In The International Encyclopedia of Interpersonal Communication; Wiley: New York City, NY, USA, 2015; pp. 1-9.

56. Kerwin, S.; Doherty, A.; Harman, A. It's Not Conflict, It's Differences of Opinion. Small Gr. Res. 2011, 42, 562-594. [CrossRef]

57. Harinck, F.; De Dreu, C.K.W.; Van Vianen, A.E.M. The Impact of Conflict Issues on Fixed-Pie Perceptions, Problem Solving, and Integrative Outcomes in Negotiation. Organ. Behav. Hum. Decis. Process. 2000, 81, 329-358. [CrossRef]

Publisher's Note: MDPI stays neutral with regard to jurisdictional claims in published maps and institutional affiliations.

(C) 2020 by the authors. Licensee MDPI, Basel, Switzerland. This article is an open access article distributed under the terms and conditions of the Creative Commons Attribution (CC BY) license (http://creativecommons.org/licenses/by/4.0/). 